\title{
Export of fresh and frozen potatoes from India - An economic analysis
}

\section{N. KuMARASAMY* AND C. SEKAR ${ }^{1}$}

Department of Agricultural and Rural Management, Centre for Agricultural and Rural Development Studies, Tamil Nadu Agricultural University, COIMBATORE (T.N.) INDIA (Email: kumarasamytnau@ gmail.com)

'Post Harvest Technology Centre, Tamil Nadu Agricultural University, COIMBATORE (T.N.) INDIA (Email: csekar2000@ gmail.com)

\section{SUMMARY :}

In India, potato is a major vegetable crop. India exported about $114,245 \mathrm{t}$ of potato to Nepal, Sri Lanka, Pakistan, Mauritius and Bangladesh (2012-13).For the study, secondary data were used. The collected data were analyzed using compound growth rate, instability index, Markov chain analysis and Nominal Protection Co-efficient (NPC). It was found that during 1990-2013, the growth rate of both fresh and frozen potatoes was positive and instability in the value of fresh and frozen potato export was high. The Markov chain analysis showed that Nepal and 'other countries' were the stable importers of fresh and frozen potatoes from India and it retained its original share of about 66 per cent and 94 per cent, respectively(2001-2011). The NPC results showed that fresh potatoes were price competitive in the international markets and have greater potential for expansion of the domestic industry in the years to come.

KEY WORDS : Fresh and frozen potatoes, Compound growth rates, Export performance, Indian potatoes, Instability, Markov Chain, NPC

How to cite this paper : Kumarasamy, N. and Sekar, C. (2014). Export of fresh and frozen potatoes from India - An economic analysis. Internat. J. Proc. \& Post Harvest Technol., 5 (2) : 173-178 